SISTEMA
ELETRONIICO
DE REVISTAS
SER I UfPR

\title{
The role of forests and protected areas in climate change mitigation: a review and critique of the ecosystem services and REDD+ approaches
}

\section{O papel das florestas e áreas protegidas na mitigação das mudanças climáticas: uma revisão e crítica das abordagens de serviços ambientais e REDD+}

\author{
Fabricio Scarpeta MATHEUS ${ }^{1 *}$ \\ ${ }^{1}$ University of Northern British Columbia, Prince George, BC, Canada. \\ *E-mail of contact: matheus@unbc.ca
}

Article received in July 28, 2017, final version accepted in May 2, 2018.

ABSTRACT: Greenhouse gas emissions are one of the biggest human impacts on the planet and are directly related to climate change. Emissions from deforestation are acknowledge as the second biggest cause of greenhouse gas emissions, accounting for up to $20 \%$ of $\mathrm{CO} 2$ equivalent released into the atmosphere in 2010 . One of the main strategies internationally adopted to reduce deforestation and forest degradation, which is now gaining importance for the climate change mitigation, is the implementation of protected areas. The current paradigm of protected area management is based on market instruments, exemplified by the REDD + initiatives and payment for ecosystem services schemes. However, critics of this perspective argue that it is directly influenced by neoliberalism and privileges capital accumulation over the conservation of the environment. Through a critical analysis of the existing literature, the present article suggests that protected areas are an efficient strategy for reducing deforestation, but it is still insufficient and needs to be accompanied by complementary actions for the control of territories outside protected areas, which prevents the redirection of illegal activities.

Keywords: protected areas; carbon storage; climate change; ecosystem services.

RESUMO: Emissões de gases de efeito estufa estão entre os principais impactos causados pelos humanos no planeta e estão diretamente ligados às mudanças climáticas. Emissões por desmatamento são reconhecidas como a segunda maior causa de emissão desses gases, contribuindo com $20 \%$ de CO2 equivalente liberado na atmosfera em 2010. Uma das principais estratégias adotadas internacionalmente para reduzir o desmatamento e a degradação florestal, e que atualmente vem ganhando importância para a mitigação das mudanças 
climáticas, é a implantação de áreas protegidas. O paradigma atual de gestão de áreas protegidas é baseado em instrumentos de mercado, exemplificado pelas inciativas de REDD + e pagamentos de serviços ambientais. Porém, críticos dessa perspectiva argumentam que ela é diretamente influenciada pelo neoliberalismo e privilegia a acumulação de capital à conservação do meio ambiente. Por meio de uma análise crítica da literatura existente, o presente artigo sugere que áreas protegidas são uma estratégia eficiente para a redução do desmatamento, porém é ainda insuficiente e precisa ser acompanhada de ações complementares para o controle de territórios fora de áreas protegidas, que evitem o redirecionamento de atividades ilegais.

Palavras-chave: áreas protegidas; estoque de carbono; mudanças climáticas; serviços ambientais.

\section{Introduction}

Anthropogenic greenhouse gas (GHG) emissions are likely to be the main cause of the climate change observed since the 1950s (Rockström et al., 2009; WWF, 2016). Emissions of carbon dioxide, methane, nitrous oxide and fluorinated gases have reached $49 \mathrm{Gt}$ of $\mathrm{CO}_{2}$ equivalent ${ }^{1}$ in 2010 , according to the most recent data released by the Intergovernmental Panel on Climate Change (IPCC, 2014). This was the highest amount ever recorded, contributing to an unprecedented concentration of these gases in the atmosphere. GHG emissions have been increasing in a faster rate since the Industrial Revolution, in the turn of the $18^{\text {th }}$ century, and this rate had been even faster in the last 40 years, when cumulative $\mathrm{CO}_{2}$ equivalent emissions almost doubled (Rockström et al., 2009; IPCC, 2014).

GHG emissions are directly related to economic growth, which can be noted by the reduction registered in 2007 and 2008, caused by the global economic crisis (IPCC, 2014). New projections from 2014 (Olivier et al., 2015) show a stagnation in global emissions, explained in most part by the reduction of the Chinese economic growth.
Nevertheless, GHG emissions are pointed as the main component of human's ecological footprint ${ }^{2}$, having raised from $43 \%$ in 1961 to $60 \%$ in 2012, according to the Global Footprint Network (2016). Other elements that are part of the ecological footprint are: cropland; forest products, and grazing land (WWF, 2016). The same study also shows that, since 1970, society demands on Earth exceeded the capacity of the planet to absorb its impacts and renew itself (Global Footprint Network, 2016).

Fossil fuel combustion, cement production and flaring are the leading causes of GHG emissions, having contributed with $78 \%$ of the total emissions in the last 40 years (IPCC, 2014). Although there are uncertainties about the estimates of emissions from deforestation, it is well accepted in the literature that it is the second biggest cause of GHG emissions, accounting for up to $20 \%$ of $\mathrm{CO}_{2}$ equivalent (Cramer et al., 2004; Scharlemann et al., 2010; IPCC, 2014). In some countries, mainly developing ones, deforestation is considered the largest cause of GHG emissions (Van der Werf et al., 2009). There are many variables that generate uncertainties about this data, such as deforestation rates and carbon density of forests (Baccini et al., 2012; Song et

\footnotetext{
${ }^{1}$ Greenhouse gas emissions are converted into $\mathrm{CO}_{2}$ equivalent based on Global Warming Potentials with a 100-year time horizon

${ }^{2}$ An ecological footprint measures humanity's demand for ecological goods and services, and “tracks how much of the planet's regenerative capacity humans demand to produce resources and to sequester waste” (Mancini et al., 2015, p. 391).
} 
al., 2015). Despite the uncertainties, it is clear that deforestation plays a major role in GHG emissions.

Scientists and policy makers have been working on several strategies to address this issue and contribute to climate change mitigation. Among the most effective plans, protected areas (PA) emerge as one of the most widespread and implemented strategy around the world as a way to reduce deforestation and forest degradation (Miranda Londono et al., 2016).

In that sense, the purpose of this paper is to discuss how PAs can be used as a strategy for climate change mitigation, reducing deforestation and storing carbon. The discussion will be held against the background of the new paradigm that influences the management of PAs, based on the concept of ecosystem services. The paper begins with the discussions of deforestation and carbon storage, followed by a review of the importance of PAs and the paradigm of ecosystem services. Then, the article presents the main criticisms of this model before the conclusion.

\section{Deforestation and land use change}

GHG emissions are caused by deforestation, or forest degradation, "through combustion of forest biomass and decomposition of remaining plant material and soil carbon" (Van der Werf et al., 2009, p. 737). In other words, it is assumed that in the long term, all carbon stored in the forest biomass and soil is released into the atmosphere. However, in order to calculate how much carbon is emitted, it is necessary to exam how the land might be used after it is cleared, since there is a great variation in the amount of carbon stored by each human activity, from pastureland to oil palm cropland, for example, or even if the area will be used for urban development (Scharlemann et al., 2010). In this sense, deforestation is not the only cause of GHG emissions, but also the type of land use.

Several studies and reports show that deforestation rates are reducing around the world and have been contributing to the decrease of GHG emissions (DeFries et al., 2007; IPCC, 2014; Song et al., 2015). Brazil, one of the biggest contributors to GHG emissions by deforestation, registered a significant reduction in the period of 2004/2017. However, this downward tendency recently suffered a meaningful change, as an increase in the deforestation rate was registered in the years of 2016 and 2017 (INPE, 2018). Notwithstanding, deforestation is still a significant driver of carbon release. A study from the World Wide Fund for Nature (WWF, 2015) shows that tropical forests are the main ecosystems under pressure and will account for approximately $80 \%$ of forest loss by 2030. Coincidently, tropical forests are also the largest global carbon stocks, as discussed in the next section.

Besides deforestation, another important factor that contributes to GHG emissions is forest degradation, especially in forest edge, the area that has direct interface with deforested regions. Studies show that degradation within $100 \mathrm{~m}$ of the forest edge may represent almost one quarter of the total GHG emissions in tropical forests (Chaplin-Kramer et al., 2015).

Despite the importance of reducing deforestation to mitigate climate change, there are still several discussions regarding the measurement of the anthropogenic impact. As suggested by Song et al. (2015), part of the uncertainty comes from 
the differences in the definition of forest loss or, as Cramer et al. (2004) state, the definitions of 'forest' versus 'non-forest' area. Technical aspects to measure these areas are also an issue. DeFries et al. (2007, p. 386) suggest that the "only practicable approach for monitoring deforestation at a national level is through interpretation of remotely sensed data". However, this statement is still subject to the same uncertainties noted above. Finally, Baccini et al. (2012) indicate that the biggest uncertainty related to deforestation and GHG emissions is attributed to the uncertainty on carbon stocks of deforested lands.

Uncertainties are always an integral part of science, especially environmental science, as Sarewitz (2004) highlights. Thus, they need to be acknowledged and used to promote a broader discussion to advance the understanding on the relationship between deforestation and climate change.

\section{Carbon storage}

Carbon is stored in all organic matters on Earth, including animals and plants, in which is commonly known as biomass. Besides, it is stored in their waste and decomposing remains. Projections show that terrestrial ecosystems store about 2,100 gigatons of carbon, three times more than the amount that is currently present in the atmosphere (Trumper, 2009).

As Corbera et al. (2010) highlight, forests play a very important role in climate change, since they store more than half of the terrestrial carbon. Tropical and subtropical forests are the biggest carbon stock on the planet, when the analysis is made according to biome, with more than one quarter of the total carbon stored on the Earth's terrestrial surface (Trumper, 2009), as shown in Table 1. However, they are also the most threatened biome by deforestation (WWF, 2015). The relation between carbon storage and biomes around the globe was assessed by Trumper (2009), combining the dataset on carbon stored in live biomass produced by Ruesch \& Gibbs (2008) and a dataset on soil carbon to $1 \mathrm{~m}$ of depth (IGBP-DIS, 2000).

Ecosystems have an important function in the carbon cycle, since $\mathrm{CO}_{2}$ is in a constant process of

TABLE 1 - Carbon stored according to biome.

\begin{tabular}{lcc}
\hline \multicolumn{1}{c}{ Biome } & Gt of C & \% \\
\hline Tropical, Subtropical Forests & 547.8 & $26.70 \%$ \\
Tropical and Subtropical Grasslands, Savannas, Shrublands & 285.3 & $13.91 \%$ \\
Deserts and Dry Shrubland & 178.0 & $8.68 \%$ \\
Temperate Grasslands, Savannas Shrublands & 183.7 & $8.95 \%$ \\
Temperate Forest & 314.9 & $15.35 \%$ \\
Boreal Forest & 384.2 & $18.73 \%$ \\
Tundra & 155.4 & $7.57 \%$ \\
Lakes & 1.0 & $0.05 \%$ \\
Rock and Ice & 1.5 & $0.07 \%$ \\
\hline Total & $\mathbf{2 0 5 1 . 8}$ \\
\hline
\end{tabular}

SOURCE: Adapted from Trumper (2009). 
emission and fixation, or sequestration. On the one hand, when an ecosystem is able to fix more carbon than emit, it is considered a carbon sink. On the other hand, if it emits more carbon than its ability to sequester it from the atmosphere, it is considered a carbon source (Cramer et al., 2004; Skutsch et al., 2007). Thus, deforestation can be interpreted as a driver that interfere in the carbon cycle equilibrium and push the ecosystem into a carbon source state.

Regarding deforestation, there are several uncertainties related to carbon storage, and most of them are connected to the forest inventories used to provide estimates on biomass. The majority of inventories are not updated and have a bias towards commercialization, since they were mostly made by the forestry industry (Baccini et al., 2012). In addition to it, the soil carbon dataset only measured carbon down to $1 \mathrm{~m}$ of depth, which possibly underestimates the amount stored.

Despite the uncertainties in different aspects of carbon storage and deforestation, several scientists and policy makers acknowledge the importance of maintaining these carbon stocks and preventing that more $\mathrm{CO}_{2}$ is released into the atmosphere. Moreover, they have been working to develop strategies to reduce deforestation. The following policies are among the main strategies identified by Corbera et al. (2010): reducing price and demand for tropical agriculture and forestry products; reducing subsidies for certain agriculture products; establishing common property regimes; paying for ecosystem services, and establishing PAs.

\section{Protected areas}

PAs have long been one of the main international strategies for biodiversity conservation (Dudley, 2008). They are an important asset in several international environmental agreements, as exemplified by the Strategic Plan for Biodiversity 2011-2020, adopted by the Convention on Biological Diversity (CBD), with its 20 Aichi Biodiversity Targets (UNEP-WCMC \& IUCN, 2016). Aichi Target 11 specifically addresses goals for PAs:

By 2020 , at least $17 \%$ of terrestrial and inland water areas and $10 \%$ of coastal and marine areas, especially areas of particular importance for biodiversity and ecosystem services, are conserved through effectively and equitably managed, ecologically representative and well-connected systems of protected areas and other effective area-based conservation measures, and integrated into the wider landscape and seascape (CBD, 2010).

Since the establishment of these targets in 2010, the number of PAs in the globe has increased. Besides, the target for marine PAs was reached in 2014. Terrestrial PAs are still below the $17 \%$ target. Nevertheless, they have experienced a noticeable growth, as shown in Figure 1, reaching 14.7\% of the terrestrial surface. Recent data account for approximately 220 thousand PAs formally created until 2016, including terrestrial, inland waters, coastal, and marine areas, which contributes to the protection of approximately 35 million $\mathrm{km}^{2}$ (UNEP-WCMC \& IUCN, 2016).

These numbers include different types of PAs, which are classified by the International Union for Conservation of Nature (IUCN) according to their objectives. The institution identifies six different 
types of PAs, ranging from more restrictive areas, such as strict nature reserves and national parks, to more permissive areas, such as PAs with sustainable use of natural resources (Dudley, 2008).

As Watson et al. (2014, p. 67) suggest, "protected areas are not a modern concept". There are records of hunting reserves from $700 \mathrm{BC}$ in the former Assyrian empire (Runte, 2010), for example. However, it was in the end of the $19^{\text {th }}$ century that the modern concept of PAs started to be implemented around the world, mainly in North America, Australia, Europe, and South Africa, with the aim at protecting iconic landscapes. Since then, this concept, including its goals and management strategies, has changed and incorporated other aspects, such as biodiversity conservation, contribution to livelihoods, and ecosystem services (Watson et al., 2014). The latter is now considered to be the main objective related to conservation in general, and specifically to the management of PAs (Emerton $e t$ al., 2006; Figgis et al., 2015).

\section{Ecosystem services}

Ecosystem services are defined by the study of the Economics of Ecosystems and Biodiversity (TEEB) as "the direct and indirect contributions of ecosystems to human wellbeing" (TEEB, 2010, p. $33)$, i.e, the beneficial services that nature provides

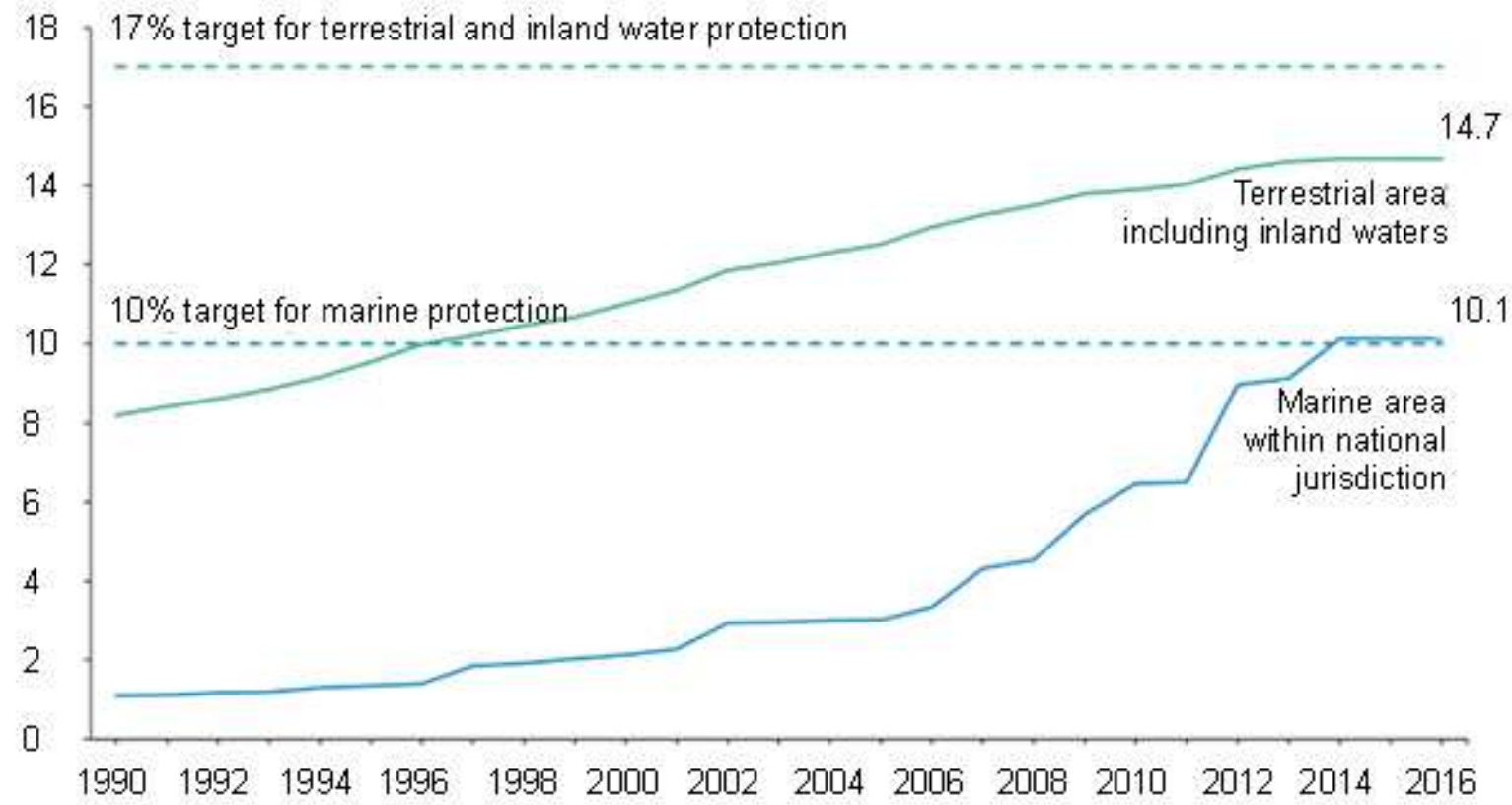

FIGURE 1 - Percentage of terrestrial and marine areas covered by protected areas by year SOURCE: Adapted from UNEP-WCMC \& IUCN (2016). 
to society. The Millennium Ecosystem Assessment (MEA, 2005) distinguishes four main types of ecosystem services: (i) provisioning services (e.g. food, raw materials, fresh water); (ii) regulating services (e.g. climate regulation, water regulation); (iii) supporting services (e.g. photosynthesis, soil formation), and (iv) cultural services (e.g. recreation and ecotourism, aesthetic values).

This concept has become the dominant conservation paradigm in the $21^{\text {st }}$ century, as reflected in the most recent definition of PAs of the IUCN: "a clearly defined geographical space, recognised, dedicated and managed, through legal or other effective means, to achieve the long-term conservation of nature with associated ecosystem services and cultural values" (Dudley, 2008, p. 8).

The IUCN further states that 'associated ecosystem services' are

related to but do not interfere with the aim of nature conservation. These can include provisioning services such as food and water; regulating services such as regulation of floods, drought, land degradation, and disease; supporting services such as soil formation and nutrient cycling; and cultural services such as recreational, spiritual, religious and other non-material benefits (Dudley, 2008, p. 9).

There are several examples of services provided by PAs. Studies show that one-third of the 100 largest cities of the world depends on PAs as a freshwater source. They also contribute to food provision by preserving the habitat of natural pollinators and fish nurseries (UNEP-WCMC \& IUCN, 2016).

The idea of a service provided by nature led to a discussion on the value of these services. This discussion first started as a metaphor to highlight the importance of nature and soon led to the development of payment for ecosystem services schemes (Norgaard, 2010). Advocates of this perspective argue that valuing ecosystem services can raise awareness from society and policy makers and promote a more rational use of the scarce conservation funds (de Groot et al., 2012).

In recent years, climate change has emerged as one of the main topics discussed among protected areas agencies, becoming an important issue on the decision-making process (Miranda Londono et al., 2016). Thus, within the concept of ecosystem services, the importance of PAs for carbon sequestration and storage has started to be promoted and studied.

\section{The role of protected areas in storing carbon}

Establishing PAs is noted as one of the most effective ways to prevent deforestation and contribute to the maintenance of carbon stocks (Melillo et al., 2016; Miranda Londono et al., 2016; UNEP-WCMC \& IUCN, 2016). Estimates indicate that PAs contain more than $15 \%$ of the carbon stored on the terrestrial surface, approximately $312 \mathrm{Gt}$ (Campbell et al., 2008). This value can be considered an underestimation, since it was made in 2008, when PAs only accounted for $12.2 \%$ of the land surface. When tropical forests are analyzed, this number is even more significant, with almost $20 \%$ of the total carbon stored in this ecosystem inside some type of PA (Scharlemann et al., 2010). Brazilian Amazon is one the most PAs, since $54 \%$ of its extent represents some form of PA (Soares et al., 2010). 
These data suggest that forests and ecosystems inside PAs usually have a higher carbon density than those not legally protected. They are also more effective as a mechanism to reduce deforestation and forest degradation. The evaluation of tropical forests from Scharlemann et al. (2010) indicates that unprotected forests lost about twice as much carbon to deforestation as the same area of protected forest. More restrictive PAs, such as parks, were identified as three times more effective in reducing GHG emissions than unprotected areas (Scharlemann et al., 2010).

PAs also have a very significant role in sequestering carbon from the atmosphere, even more effective than their storage capacity when compared to non- protected ecosystems. A recent study, based on a global biogeochemistry model, suggested that PAs can sequester $0.5 \mathrm{Gt}$ of $\mathrm{CO}_{2}$ per year, which corresponds to $20 \%$ of the total carbon sequestered by terrestrial biomes and directly contribute to climate change mitigation (Melillo et al., 2016).

Carbon storing and climate regulation can be considered public goods, as they are non-rival and non-excludable services, which means that this service does not prevent other services from being provided, and all society can use it without comprising the ability of other people to benefit from it (Barnaud \& Antona, 2014). In fact, promoting carbon storing could actually contribute to the maintenance of other services such as water provision and recreational opportunities.

International conservation institutions and NGOs have been promoting mechanisms of payment for ecosystem services as a solution for the lack of human and financial resources in PAs, among other initiatives (Emerton et al., 2006; IUCN, 2010). One of the most discussed economic tools in recent years is the mechanism of Reducing Emissions from Deforestation and Degradation (REDD).

\section{7. $R E D D+$}

The United Nations Framework Convention on Climate Change (UNFCCC) started to discuss mechanisms to reduce emissions caused by deforestation in the beginning of the 2000s with the initiative RED (Reducing Emissions from Deforestation), focusing only in deforestation. The discussions latter included forest degradation as another driver for GHG emissions, leading to the acronym REDD, which turned into REDD+ with the inclusion of forest conservation, sustainable forest management, and enhancement of forest carbon stocks, after the Bali Convention in 2007 (Angelsen et al., 2009).

The initiative aims to introduce market-based mechanisms in forest management as a way to compensate governments and landowners for the opportunity cost of protecting ecosystems (IUCN, 2010). In other words, the responsible for managing a forest would be paid to stop deforestation and would be compensated for the economic activity that they were prevented from doing. The strategy is geared towards developing countries, where the largest extents of forests are located and which are mainly funded by the UNFCC and the World Bank (McAfee, 2015).

Currently, only a few REDD+ projects are implemented around the world (McAfee, 2015), but there are already studies that evaluate their results. One of them was developed by the government of 
Amazonas in Brazil and is called Forest Grant ${ }^{3}$. In this program, families receive an annual grant for developing activities that are in line with the management plan of the PA (i.e., reducing deforestation) (Börner et al., 2013). However, other studies suggest that the influence of an international market can intensify environmental injustices and threaten the livelihoods of local communities by dispossessing them and increasing inequity, as Beymer-Farris \& Bassett (2012) highlighted in an example from Tanzania.

\section{Criticisms of the Ecosystem Services and REDD+ Approaches}

Conservation institutions are promoting market-based mechanisms in what they call a win-win strategy, in which all actors involved can benefit somehow, such as REDD+ schemes (Igoe \& Brockington, 2007). They advocate that it is possible to maintain economic growth and increase nature conservation, reducing GHG emissions and mitigating climate change effects at the same time.

However, several authors suggested that these initiatives are heavily influenced by neoliberalism, calling them a form of neoliberal conservation (Igoe \& Brockington, 2007; Castree, 2008; Büscher et al., 2012). Based on the neoliberal narrative of lack of funding and resources available for conservation, especially in relation to PAs, neoliberal conservation advocates that market-based strategies are not just the best, but the only way to protect nature.

On the other hand, authors who are critical of this approach draw attention to the contradiction that neoliberalism is promoting nature conservation using strategies that led to deforestation and forest degradation in the first place. As Hajer (1995) suggested, the modern concept of conservation advocates that it is possible to deal with complex environmental issues without significant changes in existing social structures and institutions. Büscher et al. (2012) highlighted that under neoliberalism, nature needs to be profitable, or as they stated "in order for natures to be 'saved', acts of 'nature saving' must be imbued with profit potential or else there is little incentive for rational actors to pursue it" (p. 13).

Market-based strategies have been used since the establishment of the first modern PAs in the $19^{\text {th }}$ century (e.g., concessions, user fees) (Runte, 2010). However, since the 2000 s, with the shift to the ecosystem services paradigm, the influence of neoliberalism affected conservation in a more substantial way. The current conservation paradigm is characterized by processes and actions directly connected to neoliberalism, such as the commodification of nature, increased participation of the private sector, and reregulation processes that aim to benefit specific sectors of the market (Igoe \& Brockington, 2007; Castree, 2008).

Despite the promotion of market-based strategies by the main conservation organizations around the word, several studies suggested that the paradigm of the ecosystem services caused negative impacts on PAs, mainly on local communities. An attempt to establish a carbon market in Uganda was unable to achieve its objectives on carbon sequestration and led to the eviction of the local people, without any compensation for their loss of land, property, and livelihoods (Cavanagh \& Benjaminsen, 2014). Moreover, a study from Mozambique demonstrated how the implementation of a private conservancy to curb rhino poachers, near 
the border with South Africa, became the reason for the displacement of local communities and created a private securitized wildlife frontier (Massé \& Lunstrum, 2016).

REDD+ schemes are considered an "archetypal application of green-economy logic" (McAfee, 2015 , p. 15). However, such schemes are accused of threatening the sovereignty of Third World countries, which are subjected to the economic power of developed countries and international institutions, such as the World Bank, in what is known as new or green imperialism (McAfee, 2015). Other authors suggest that the monetarization process increases the distance between nature and society, who sees it as a product for consumption (Barnaud \& Antona, 2014). Others even indicate that market mechanisms intensify inequity, and vulnerable communities are usually more affected, being displaced from their lands and pushed into more precarious conditions (Beymer-Farris \& Bassett, 2012).

\section{Conclusion}

PAs are considered a highly effective strategy to reduce deforestation and also deliver other ecosystem services. However, it is also important to promote other approaches for reducing deforestation as it is not feasible to expand PAs indefinitely, even if Aichi target 11 is reached and surpassed. In addition, for instance in the Brazilian case, private property was the land category that contributed the most for deforestation, reaching $35 \%$ of the total amount in 2016 (Azevedo et al., 2016).

In this sense, sustainable forest management and other types of land use management for private landowners should also be discussed and promoted, as they can be even more effective in delivering some types of benefits without meaningful restrictions (Miles \& Kapos, 2008). PAs can also cause what is known as leakage, i.e., redirect deforestation to less regulated places (Soares et al., 2010). Therefore, attention to non-protected areas should be increased in order to avoid this process and create new economic opportunities to generate jobs and income as an alternative to more extractive activities.

Examples of strategies to reduce deforestation and increase conservation outside PAs are: measures to facilitate credit for landowners who develop sustainable practices; increased capacity for monitoring and remote sensing; smarter regulation and enforcement (e.g., the environmental land registration in Brazil); participatory planning and awareness campaigns among private owners, focusing not only on small but also large properties, and support for the establishment of private PAs (Azevedo et al., 2016). These are just a few alternatives found in the literature that have already proven to be effective and do not exhaust the discussion.

In addition, PAs are not as efficient as they could be, mainly because of the lack of resources for monitoring and law enforcement, which allows for illegal activities to continue inside their borders. Therefore, market-based mechanisms, such as REED + schemes, have been promoted as one of the main strategies to overcome this issue. However, critics of this position suggest that a neoliberal approach will only increase inequity and the challenges faced by society.

Regardless of the stance on this issue, it is clear that ecosystem services are the main concept behind the present conservation paradigm and are directly influencing the way PAs are managed around the world. It is also clear that PAs are an 
important tool for reducing deforestation and GHG emissions, contribute to carbon sequestration, and function as carbon sinks. In this sense, more studies to better assess carbon stocks, improve deforestation monitoring, and evaluate REDD+ impacts are necessary, not only as forms to reduce uncertainties, but to better understand them and promote better informed decisions. As Allen et al. (2001) suggest, in a postmodern world, there is no truth, but only narratives. Besides, scientists and policy makers need to understand the different narratives and make decisions informed as to the consequences of each one and assume responsibility for them.

\section{References}

Allen, T. F. H.; Pires, J. C.; Tainter, J.; Hoekstra, T. W. Dragnet Ecology: "Just the facts Ma'am": The privilege of Science in a Postmordern World. BioScience, 51(6), 475-485, 2001. doi: 10.1641/0006-3568(2001)051

Angelsen, A.; Brown, S.; Loisel, C. Reducing emissions from deforestation and forest degradation (REDD): an options assessment report, 2009. Disponível em <http:// www.redd-oar.org/>. Acesso em: nov. 2016.

Azevedo, A.; Alencar, A.; Moutinho, P.; Ribeiro, V.; Reis, T.; Stabile, M.; Guimarães, A. Panorama sobre o desmatamento na Amazônia em 2016. Brasília, DF: IPAM, 2016. Disponível em: http://ipam.org.br/wp-content/uploads/2016/12/ panorama-desmatamento-amazônia-2016.pdf

Baccini, A.; Goetz, S. J.; Walker, W. S.; Laporte, N. T.; Sun, M.; Sulla-Menashe, D.; ... Houghton, R. A. Estimated carbon dioxide emissions from tropical deforestation improved by carbon-density maps. Nature Climate Change, 2(3), 182-185, 2012. doi: 10.1038/nclimate 1354

Barnaud, C.; Antona, M. Deconstructing ecosystem services: Uncertainties and controversies around a socially constructed concept. Geoforum, 56, 113-123, 2014. doi: 10.1016/j.geoforum.2014.07.003
Beymer-Farris, B. A.; Bassett, T. J. The REDD menace: Resurgent protectionism in Tanzania's mangrove forests. Global Environmental Change, 22(2), 332-341, 2012. doi: 10.1016/j.gloenvcha.2011.11.006

Börner, J.; Wunder, S.; Reimer, F.; Bakkegaard, R. K.; Viana, V.; Tezza, J.; ... Marostica, S. Promoting forest stewardship in the Bolsa Floresta Programme: local livelihood strategies and preliminary impacts. Rio de Janeiro, Brazil: Center for International Forestry Research (CIFOR). Manaus, Brazil: Fundação Amazonas Sustentável (FAS). Bonn, Germany: Zentrum für Entwicklungsforschung (ZEF), University of Bonn, 2013. Diponível em: http:// fas-amazonas.org/versao/2012/wordpress/wp-content/ uploads/2014/02/BF_report_ENG_web.pdf

Büscher, B.; Sullivan, S.; Neves, K.; Igoe, J.; Brockington, D. Towards a Synthesized Critique of Neoliberal Biodiversity Conservation. Capitalism Nature Socialism, 23(2), 4-30, 2012. doi: 10.1080/10455752.2012.674149

Campbell, A.; Miles, L.; Lysenko, I.; Gibbs, H.; Hughes, A. Carbon storage in protected areas: Technical report, 2008. Disponível em $<$ http://citeseerx.ist.psu.edu/viewdoc/ download?doi=10.1.1.378.5242\&rep=rep $1 \&$ type $=p d f>$. Acesso em: nov. 2016.

Castree, N. Neoliberalising nature: Processes, effects, and evaluations. Environment and Planning A, 40(1), 153-173, 2008. doi: 10.1068/a39100

Cavanagh, C.J.; Benjaminsen, T.A. Virtual nature, violent accumulation: The "spectacular failure" of carbon offsetting at a Ugandan National Park. Geoforum, 56, 55-65, 2014. doi: 10.1016/j.geoforum.2014.06.013

CBD - Convention on Biological Diversity. Decision adopted by the conference of the parties to the convention on biological diversity at its tenth meeting, 2010. Disponível em $<$ https://www.cbd.int/doc/decisions/cop-10/cop-10-dec-02-en.pdf $>$. Acesso em: nov. 2016.

Chaplin-Kramer, R.; Ramler, I.; Sharp, R.; Haddad, N. M.; Gerber, J. S.; West, P. C.; ... King, H. Degradation in carbon stocks near tropical forest edges. Nature Communications, 6, 10158, 2015. doi: 10.1038/ncomms10158

Corbera, E.; Estrada, M.; Brown, K. Reducing greenhouse gas emissions from deforestation and forest degradation in 
developing countries: Revisiting the assumptions. Climatic Change, 100(3), 355-388, 2010. doi: 10.1007/s10584-0099773-1

Cramer, W.; Bondeau, A.; Schaphoff, S.; Lucht, W.; Smith, B.; Sitch, S. Tropical Forests and the Global Carbon Cycle: Impacts of Atmospheric Carbon Dioxide, Climate Change and Rate of Deforestation. Philosophical Transactions: Biological Sciences, 359(1443), 331-343, 2004. doi: $10.2307 / 4142186$

DeFries, R.; Achard, F.; Brown, S.; Herold, M.; Murdiyarso, D.; Schlamadinger, B.; de Souza, C. Earth observations for estimating greenhouse gas emissions from deforestation in developing countries. Environmental Science and Policy, 10(4), 385-394, 2007. doi: 10.1016/j.envsci.2007.01.010

de Groot, R.; Brander, L.; van der Ploeg, S.; Costanza, R.; Bernard, F.; Braat, L.; ... van Beukering, P. Global estimates of the value of ecosystems and their services in monetary units. Ecosystem Services, 1(1), 50-61, 2012. doi: 10.1016/j. ecoser.2012.07.005

Dudley, N. Guidelines for Applying Protected Area Management Categories. Gland, Switzerland: IUCN, 2008. Disponível em: http://cmsdata.iucn.org/downloads/guidelines_for_applying_protected_area_management_categories.pdf

Emerton, L.; Bishop, J.; Thomas, L. Sustainable financing of protected areas. A global review of challenges and options. Gland, Switzerland: IUCN, 2006. Disponível em: https://www.iucn.org/content/sustainable-financing-protected-areas

Figgis, P.; Mackey, B.; Fitzsimons, J.; Irving, J.; Clark, P. Valuing Nature: Protected Areas and Ecosystem Services. Sydney, Australia: Australian Committee for IUCN, 2015. Disponível em: http://aciucn.org.au/index.php/publications/ 2015-valuing-nature/

Global Footprint Network. National Footprint Accounts, 2016. Disponível em <http://www.footprintnetwork.org/ en/index.php/GFN/page/public_data_package $>$. Acesso em: nov. 2016.

Hajer, M. A. The politics of environmental discourse: ecological modernization and the policy process. Oxford: Clarendon Press, 1995.
IGBP-DIS. Global Gridded Surfaces of Selected Soil Characteristics. Oak Ridge National Laboratory Distributed Active Archive Center, Oak Ridge, USA, 2000. Disponível em: https://daac.ornl.gov/cgi-bin/dsviewer.pl?ds_id=569

Igoe, J.; Brockington, D. Neoliberal conservation: Abrief introduction. Conservation and Society, 5(4), 432-449, 2007. Disponível em: http://www.conservationandsociety.org/article. asp?issn=0972=4923-;year2007=;volume5=;issue4=;spage432; epage $=449$; aulast $=$ Igoe; type $=0$

INPE - Instituto Nacional de Pesquisas Espaciais. Monitoramento da Floresta Amazônica Brasileira por Satélite, 2018. Disponível em: http://www.obt.inpe.br/OBT/assuntos/programas/amazonia/prodes. Acesso em: mar. 2018.

IPCC - Intergovernmental Panel on Climate Change. Climate Change 2014: Mitigation of Climate Change. Working Group III Contribution to the Fifth Assessment Report of the Intergovernmental Panel on Climate Change. Edenhofer, O.; R. Pichs-Madruga, Y.; Sokona, E.; Farahani, S.; Kadner, K.; Seyboth, A.; Adler, I.; Baum, S.; Brunner, P.; Eickemeier, B.; Kriemann, J.; Savolainen, S.; Schlömer, C.; von Stechow, T.; Zwickel and J.C. Minx (eds.). Cambridge University Press, Cambridge, United Kingdom, 2014. Disponível em: https://www.ipcc.ch/pdf/assessment-report/ar5/ wg3/ipcc_wg3_ar5_frontmatter.pdf

IUCN - International Union for Conservation of Nature. Saving biodiversity: an economic approach. World Conservation, 40(1), 42, 2010. Disponível em: https://cmsdata. iucn.org/downloads/101252_uicn_24pp.pdf

Massé, F.; Lunstrum, E. Accumulation by securitization: Commercial poaching, neoliberal conservation, and the creation of new wildlife frontiers. Geoforum, 69, pp.227-237, 2016. doi: 10.1016/j.geoforum.2015.03.005

Mancini, M. S.; Galli, A.; Niccolucci, V.; Lin, D.; Bastianoni, S.; Wackernagel, M.; Marchettini, N. (2015). Ecological Footprint: Refining the carbon Footprint calculation. Ecological Indicators, 61, 390-403, 2015. doi: 10.1016/j. ecolind.2015.09.040

McAfee, K. Green economy and carbon markets for conservation and development: a critical view. International Environmental Agreements: Politics, Law and Economics, 1-21, 2015. doi: 10.1007/s10784-015-9295-4 
MEA - Millennium Ecosystem Assessment. Ecosystems and Human Well-being: Current States and Trends. Island Press, Washington, DC, 2005. Disponível em: https://islandpress. org/book/ecosystems-and-human-well-being-current-state-and-trends

Melillo, J. M.; Lu, X.; Kicklighter, D. W.; Reilly, J. M.; Cai, Y.; Sokolov, A. P. Protected areas' role in climate-change mitigation. Ambio, 45(2), 133-145, 2016. doi: 10.1007/ s13280-015-0693-1

Miles, L.; Kapos, V. Reducing greenhouse gas emissions from deforestation and forest degradation: global land-use implications. Science, 320(5882), 1454, 2008. doi: 10.1126/ science. 1155358

Miranda Londono, J.; Prieto Albuja, F. J.; Gamboa, P.; Gorricho, J.; Vergara, A.; Welling, L.; ... Dudley, N. Editorial: Protected areas as natural solutions to climate change. Parks, 22(1), 7-12, 2016. Disponível em: 10.2305/IUCN.CH.2016. PARKS-22-1JML.en

Norgaard, R. B. Ecosystem services: From eye-opening metaphor to complexity blinder. Ecological Economics, 69(6), 1219-1227, 2010. doi: 10.1016/j.ecolecon.2009.11.009

Olivier, J.; Janssens-Maenhout, G.; Muntean, M.; Peters, J. Trends in global CO2 emissions: 2015 Report. European Commission, 2015. Disponível em < http://edgar.jrc. ec.europa.eu/news_docs/jrc-2015-trends-in-global-co2-emissions-2015-report-98184.pdf>. Acesso em: nov. 2016.

Rockström, J.; Steffen, W.; Noone, K.; Persson, Å.; Chapin, F. S.; Lambin, E. F.; ... Nykvist, B. A safe operating space for humanity. Nature, 461(7263), 472-475, 2009. doi: $10.1038 / 461472 \mathrm{a}$

Ruesch, A; Gibbs, H. New IPCC Tier-1 Global Biomass Carbon Map for the Year 2000, 2008. Disponível em <http:// cdiac.ornl.gov/epubs/ndp/global_carbon/carbon_documentation.html>. Acesso em nov. 2016.

Runte, A. National Parks: the American history. Lanham, USA: Taylor Trade Publishing, 4. ed., 2010.

Sarewitz, D. How science makes environmental controversies worse. Environmental science \& policy, 7(5), 385-403, 2004. doi: 10.1016/j.envsci.2004.06.001

Scharlemann, J. P. W.; Kapos, V.; Campbell, A.; Lysenko,
I.; Burgess, N. D.; Hansen, M. C.; ... Miles, L. Securing tropical forest carbon: the contribution of protected areas to REDD. Oryx, 44(3), 352-357, 2010. doi: 10.1017/ S0030605310000542

Skutsch, M.; Bird, N.; Trines, E.; Dutschke, M.; Frumhoff, P.; de Jong, B. H. J.; ... Murdiyarso, D. Clearing the way for reducing emissions from tropical deforestation. Environmental Science and Policy, 10(4), 322-334, 2007. doi: 10.1016/j.envsci.2006.08.009

Soares, B.; Moutinho, P.; Nepstad, D.; Anderson, A.; Rodrigues, H.; Garcia, R.; ... Maretti, C. Role of Brazilian Amazon protected areas in climate change mitigation. Proceedings of the National Academy of Sciences of the United States of America, 107(24), 10821-10826, 2010. doi: 10.1073/pnas.0913048107

Song, X. P.; Huang, C.; Saatchi, S. S.; Hansen, M. C.; Townshend, J. R. Annual carbon emissions from deforestation in the Amazon basin between 2000 and 2010. PLoS ONE, 10(5), 1-21, 2015. doi: 10.1371/journal.pone.0126754

TEEB - The Economics of Ecosystems and Biodiversity. The Economics of Ecosystems and Biodiversity: Mainstreaming the Economics of Nature. A Synthesis of the Approach, Conclusions and Recommendations of TEEB, 2010. Disponível em <http:/www.teebweb.org/publication/ mainstreaming-the-economics-of-nature-a-synthesis-of-the-approach-conclusions-and-recommendations-of-teeb/>. Acesso em nov. 2016.

Trumper, K. The Natural Fix?: The Role of Ecosystems in Climate Mitigation: a UNEP Rapid Response Assessment, 2009. Disponível em $<\mathrm{http} / / /$ staging.unep.org/pdf/BioseqRRA_scr.pdf $>$. Acesso em nov. 2016.

UNEP-WCMC \& IUCN. Protected Planet Report 2016. Gland, Switzerland: UNEP-WCMC \& IUCN, 2016. Disponível em: https://www.protectedplanet.net/c/protected-planet-report-2016

Van der Werf, D; Morton, D. C.; DeFries, R. S.; Olivier, J. G. J.; Kasibhatla, P. S. CO2 emissions from forest loss. Nature Geoscience, 2(11), 737-738, 2009. doi: 10.1038/ngeo671

Watson, J. E. M.; Dudley, N.; Segan, D. B.; Hockings, M. The performance and potential of protected areas. Nature, 515(7525), 67-73, 2014. doi: 10.1038/nature13947 
WWF. Living Forests Report, 2015. Disponível em $<$ http:// wwf.panda.org/about_our_earth/deforestation/forest_publications_news_and_reports/living_forests_report/ $>$. Acesso em: nov. $201 \overline{6}$.
WWF. Living Planet Report 2016. Risk and resilience in a new era, 2016. Disponível em <http://wwf.panda.org/ about_our_earth/all_publications/lpr_2016/>. Acesso em: nov. 2016. 